\title{
The connection of socio-demographic factors and child-parent relationships to the psychological aspects of children's development
}

\author{
Vladimir S. Sobkin ${ }^{\mathrm{a}, \mathrm{b}^{*}}$, Aleksandr N. Veraksa ${ }^{\mathrm{b}}$, Darya A. Bukhalenkova ${ }^{\mathrm{b}}$, \\ Aleksandra V. Fedotova ${ }^{a}$, Ulia A. Khalutina ${ }^{\mathrm{a}}$, Vera A. Yakupova ${ }^{\mathrm{b}}$ \\ ${ }^{a}$ Institute for the Management of Education of the Russian Academy of Education, Moscow, Rus- \\ sia \\ ${ }^{b}$ Faculty of Psychology, Lomonosov Moscow State University, Moscow, Russia \\ * Corresponding author. E-mail: sobkin@mail.ru
}

Preschool childhood is a time of rapid development. During this period a child's interaction with significant adults plays a very important role. The parent, as a mediator, defines the "zone of proximal development" (Vygotsky, 1984). The common assumption is that to determine a parent's position, it is important to acknowledge both socio-demographic factors and the parameters which define the socio-psychological aspects of parent-child relationship. Hence, the type of research where a child's psychological development is studied in the context of the socio-demographic and socio-psychological factors which determine the social situation of development, is very promising.

Based on our previous research (Sobkin, Marich, 2002; Cheie, Veraksa, 2015), a program of experimental research intended to determine the interconnections between the socio-demographic and socio-psychological parameters of parent-child relationships, and the level of a child's psychic development, was designed. The research was based upon the material obtained through testing 59 children between 5 and 7 years old with specially collected psychological testing methods (Veraksa A.N. etc), as well as from the results of a special sociological questionnaire presented to their mothers (Sobkin V.S. etc). The research was carried out in 2014-2015 in municipal kindergartens of Moscow.

Among the socio-demographic factors analyzed, the most significant results were related to the child's gender, the family structure, and the mother's education. Thus, boys showed higher results on visual memory tests, and girls scored better on tests for self-control and social intelligence (higher ability to detect the reason for someone else's negative emotions). Children from single-parent families had better results on verbal memory tests, but scored lower on those for self-control. Also they had less ability for decentration. The differences in mothers' educational levels influenced the number and intensity of children's fears, as well as their inclinations to avoid fearsome situations. 
The analysis of features of the parenting position (such as attitude toward one's future, positive/negative emotional state during the interaction with the child, authoritative/democratic approach to upbringing) revealed two different strategies which children used to perform executive tasks.

Thus, the present research showed a significant degree of essential connections between socio-demographic factors and parent-child relationships to the specifics of a child's mental development.

Keywords: child development, preschool age, social situation of development, parentchild relationships, executive functions, social intelligence

\section{Introduction}

The cultural-historical activity theory states that the environment which surrounds a child is crucial to his/her development. Various factors of the social situation of development may enhance a child's mental development, or undermine it (Bozhovich, 2008; Dumitrashku, 1996; Elkoin, 1960; Lisina, 2009; Vygotsky, 1984; Zaporozhets, 1965; Kovan, Kovan, 1989). However, while researchers in the 1950-1970s focused more on the common tendencies and periodization of the formation of mental functions (Vygotsky, 1984; Lisina, 2009; Elkoin, 1960), nowadays attention has been shifted to the specific development of psychological functions at a certain age (Bjorklund, Kipp, 1996; Carlson, Moses, 2001; Smirnova, 1998; Sobkin, Skobeltsina, Ivanova, \& Veryasova, 2013).

Preschool childhood is a time when a growing child develops rapidly. During this stage of life, mental processes become mediated and self-regulated, and the child's thinking undergoes decentration (Lisina, 2009; Elkoin, 1960; Vygotsky, 1984; Zaporozhets, 1965). According to L.S. Vygotsky (1984), the key role is played by an important adult who fulfills an intermediary function, defining the child's views of the world and determining their zone of proximal development.

Thus, research which complements the study of children's individual psychological features with a description of various factors in the child's social situation of development (socio-demographics, parent-child relationships) is very important both for theoretical and practical psychology. This kind of research is actively carried out abroad. Researchers analyze the connection between the developmental process and such socio-demographic factors as the parents' educational level, family structure, SES (socio-economic status), etc. Most of the research shows a significant correlation between the development of children's executive functions and the parents' level of education, housing conditions, and the presence of both parents in the household (Alarcón-Rubio, Sánchez-Medina, \& Prieto-García, 2014; Anastasy, 1956; Ardila, Rosselli, Matute, \& Guajardo, 2005; Belmont, Marolla, 1973; Bulgarelli, Molina, 2016; Filippetti, Richaud, 2012; Fitzpatrick, McKinnon, Blair, \& Willoughby, 2014; Sarsour, Sheridan, Jutte, Nuru-Jeter, Hinshaw, \& Boyce, 2010; Willoughby, Wirth, Blair \& The Family Life Project Investigators, 2012).

Plenty of research deals with parenting and the way it relates to the development of child's executive functioning. Most focuses on the effect that the maternal parenting style and supportive behavior have on preschoolers' executive functions 
and problem solving (Blair, Raver, Berry, \& Family Life Project Investigators, 2014; Hammond, Müller, Carpendale, Bibok, \& Liebermann-Finestone, 2012; Leerkes, Blankson, O’Brien, Calkins, \& Marcovitch, 2011; Lucassen et al., 2015; Matte-Gagné, \& Bernier, 2011; Ursache, Blair, Stifter, \& Voegtline, 2013). This can be understood in relation to the time that parents spend with their children: in the vast majority of families, mothers still spend more time taking care of their children than fathers do. Thus, Roskam, Stievenart, Meunier \& Noel (2014) showed that both mothers and fathers contribute through their child-rearing behavior to their children's executive functioning, but the mothers' effect on children's development of inhibition was more pronounced than that of the fathers.

In some of the Russian studies, the specific characteristics of a child's development are also associated with his/her family's socio-demographic parameters and his/her parents' upbringing style (Andreeva, 1994; Chernov, 2009; Dumitrashku, 1996; Kochetova, 2012; Smirnova, Sobkin, Asadulina, \& Novakovskaya, 1999; Sobkin et al., 2013). In one of our previous studies (Sobkin, Marich, 2002), the difference between the cognitive and emotional development of boys and girls living in one-parent families was revealed. However, in this research we used the Venger test for cognitive development and a picture test for emotional perception of the family; therefore it is quite difficult to compare the results of this work with modern investigations done abroad.

Lately the NEPSY-II set of neuropsychological tests has become rather commonly used for studies of preschool children's mental development (Korkman, 1999; Korkman, Kirk \& Kemp, 2007; Visu-Petra, Cheie, Benga, \& Miclea, 2012). For example, this battery was used in a cross-cultural study of Romanian and Russian preschool children (Cheie, Veraksa, Zinchenko, Gorovaya, \& Visu-Petra, 2015). It showed a difference between children's levels of anxiety in these countries, which the authors interpreted as an important factor in the development of executive functions in children between 5 and 7 years of age.

In general, analysis of the literature allows us to conclude that in the field of child development, a special line of psychological research has been developed which includes analysis of both the socio-psychological and the socio-demographic parameters that characterize a child's social situation of development. However, the specific interrelationships between socio-demographic factors, parent-child relationships, and particular features of the child's mental development are yet to be studied and clarified. The present study was carried out to pursue these relationships.

\section{Method}

\section{Sample}

The basis for this article is material obtained through psychological testing of children between 5 and 7 years of age in municipal kindergartens in Moscow, as well as the results of a questionnaire filled out by their parents. Mothers were more likely to respond (due to the fact that some of the families were single-parent, and some of the fathers refused to participate). In this regard we selected results from 59 children whose mothers also took part in the investigation. 


\section{Research methods}

Researchers from the Center for Sociology of Education (dir. V.S. Sobkin) for the Russian Academy of Education, in partnership with a study group of the faculty of psychology at Lomonosov Moscow State University (dir. A.N. Veraksa), have prepared a research program designed to compare the socio-demographic factors and the psychological aspects of parent-child relationships, with the characteristics of children's mental development. To achieve this goal, the design of the research included testing of preschool children and a sociological questionnaire for their parents.

According to the research program, a set of methods was selected to describe various aspects of an older pre-school child's mental development.

The majority of these methods are Russian versions of subtests from the neuropsychological complex NEPSY-II, which is designed to evaluate the mental development of children between 3 and 16 years old (Korkman, 1999; Korkman et al., 2007). According to the authors of this complex, it is based on the culturalhistorical activity theory largely represented in the works of A.R. Luria. Previous research had shown the possibility of using these methods on the Russian children (Cheie et al., 2015). The selected subtests were complemented by a number of additional methods widely used outside Russia. This allowed the creation of a new testing program for older pre-school children, which includes three complementary methods designed to measure social intelligence, cognitive development, and the development of executive functions.

The first module is intended to diagnose the child's level of social and emotional intelligence. It includes the following methods: Theory of Mind, Affect Recognition, Test of Emotion Comprehension, and Picture Anxiety Test.

Theory of Mind (NEPSY-II) is intended to measure the child's ability to analyze situations and interpret another person`s thoughts and feelings.

Affect Recognition (NEPSY-II) is designed to measure the child's ability to detect emotions by facial expressions (joy, sadness, calm, fear, anger, revulsion).

The Test of Emotion Comprehension (TEC) (Pons, Harris, 2000; Pons, Harris, \& de Rosnay, 2004) is designed to evaluate how well children understand various emotions which may show up in different situations, and how they understand their causes.

The Picture Anxiety Test (PAT) (Dubi, Schneider, 2009; Dubi, Schneider, \& Lavellee, 2012) allows us to measure the level of a child's fear, and the degree of his/ her inclination to avoid typically fearsome situations.

The second module is dedicated to the study of the child's cognitive level, memory, and learning ability. It includes such methods as the colored Raven's Progressive Matrices, Memory for Designs, and Sentence Repetition.

Raven's Progressive Matrices (Raven, Raven, \& Court, 1998) are widely known and used to measure a child 's nonverbal intelligence.

Memory for Designs (NEPSY-II) was used to measure the level of development of visual memory and a child's ability to memorize integral configurations of objects and details of images.

Sentences Repetition (NEPSY-II) measures a child's ability to perceive, store, and reproduce verbal information. 
The third module includes methods that allow us to diagnose the level of development of executive functions and cognitive flexibility: namely, the Inhibition test and Dimensional Change Card Sort.

The Inhibition test (NEPSY-II) was used to measure the level of the child's development of executive functions.

The Dimensional Change Card Sort (DCCS) (Zelazo, 2006) is dedicated to measuring the child's ability to regulate his/her behavior according to complex rules, which allows the child to evaluate his/her level of self-control and cognitive flexibility.

A special questionnaire was used for the mothers' survey. It was developed by the research group of the Center for the Sociology of Education of IME RAE, and includes 100 questions which evaluate various aspects of a preschool child 's life (Sobkin, \& Marich, 2002; Sobkin, \& Skobeltsina, 2011; Sobkin, Skobeltsina, \& Ivanova, 2011; Sobkin, Skobeltsina 2015). We picked only those questions which allow us to characterize the child's social situation of development. Firstly, we used questions concerning socio-demographic factors (the child's gender, family structure, mother's educational level). Secondly, we picked questions about the interaction between mother and child, and the style of communication (authoritarian/ democratic).

The whole set of tasks was split up and carried out over three meetings, each 20-25 minutes long. The parents were given the questionnaires which they could fill out at home in their spare time.

While planning the research program, we suggested that there is a connection between child 's success at given tasks and the parameters of his social situation of development as indicated in the questionnaire.

During the processing and analysis of the data, we used average values based on raw data points, since the norms for the applied psychological methods have not yet been completely adopted in Russia.

\section{Results}

The data we received is presented in two parts. The first part is dedicated to analyzing the connection between children's levels of development and such sociostratifying and demographic factors as gender, family structure, and the mothers' level of education. The second part deals with the connection of the children's level of development to features of the mother's attitude toward life and parenting strategy: the parenting style (authoritarian/democratic), comprehension of the future (optimism/doubt), and the mother's emotional state during interaction with the child (positive/negative).

\section{The influence of socio-stratifying factors on the child's mental development}

Gender differences. The data we obtained showed that boys are better at memorizing visual information (Memory for Designs method). A statistically significant difference appears in the $4^{\text {th }}$ test: 22.3 points for boys and 17.9 for girls $(\mathrm{p} \leq .04)$. This test is notable because it is secondary, i.e. the child is offered the same configu- 
ration of cards twice. The successful passing of the $4^{\text {th }}$ test may be a sign that boys have higher ability to use previous experience and higher learning ability.

At the same time, girls show higher results in the Dimensional Change Card Sort (DCCS) in the task with "borders" (8.2 and 6.3 respectively; $\mathrm{p} \leq .05)$. In this task children are asked to sort cards first by one parameter (color), then by another (shape). After the child grasps the rules for sorting, he/she is offered a $3^{\text {rd }}$ more complicated task with "borders," where the rule calls for sorting cards by one or another parameter depending on additional information (frame on the cards). Thus, girls' more successful implementation of this harder task indicates their higher cognitive flexibility.

Furthermore, differences between boys and girls were detected through the second method, Inhibition, designed to diagnose the development of executive functions. Children are given two lists of pictures: the first had figures (circles and rectangles), the second had arrows (up and down). Both lists included two tests: "naming" and "inhibition." In the test for "naming," a child had to name the figures (circle/rectangle) and the direction of arrows (up/down) which are shown in the picture. The second test ("inhibition") required naming figures and directions of arrows opposite to those which were actually pictured in the picture (i.e. instead of the pictured circle, say, "rectangle").

In these tasks boys made more mistakes in the tests for naming figures than girls (4.0 and 2.2 respectively; $\mathrm{p} \leq .05)$ and made more corrections (2.0 and 0.9 respectively; $\mathrm{p} \leq .01)$. Thus, boys were less attentive and careful while performing this task, so they had to correct themselves more. In the tests for inhibition with arrows (children were asked to name directions of arrows opposite to those which were actually pictured), boys had a larger number of mistakes in general (10.6 and 6.8 respectively; $\mathrm{p} \leq .04$ ), as well as more uncorrected mistakes ( 8.2 and 4.3 respectively; $\mathrm{p} \leq .04$ ). This was the final task presented by this method; thus the increased number of mistakes may indicate that boys tire more quickly, consequently making more mistakes and correcting them less effectively.

The results from the methods that evaluate executive functions show that girls display better self-control than boys; they are more attentive in completing tasks, and are able to follow difficult rules and stay focused for a longer period of time.

Tests for emotion recognition (Affect Recognition method) also presented a range of significant differences (Figure 1). In these tests, the top of the page displayed a child in a certain emotional state, and below were pictures of four other children showing different emotions. The participant was asked to point out which one of the children displayed below was feeling the same way as the child at the top of the page. The percentage of girls who correctly indicated sadness $(p \leq .04)$ and neutrality $(\mathrm{p} \leq .01)$ was higher than that of the boys. The boys were better in recognizing anger $(\mathrm{p} \leq .03)$.

These differences may be explained by culturally determined parenting strategies for both genders: boys are traditionally forbidden to display sadness, while for girls it is socially acceptable (Kon, 2003). At the same time, girls are not allowed to show anger, while for boys, who are by and large the ones who take part in conflicts and fights with peers, this emotion is considered more essential; sometimes they are even encouraged to express this feeling. 


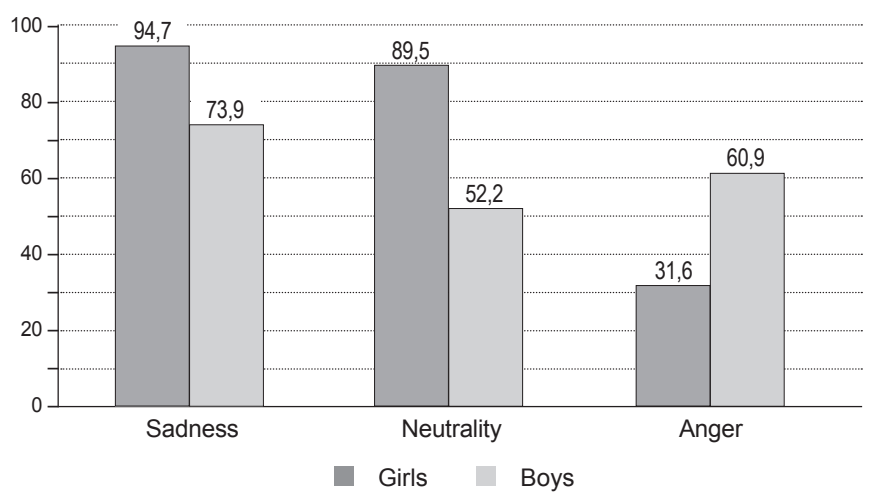

Figure 1. Gender differences in correct recognition of various emotions (\%)

Obvious gender differences were found in task No. 5 of the Theory of Mind method. This task requires the child to answer which one of three girls gets to hug dolphins in real life: Annie, who lives by the ocean, and whose dad lets her swim with dolphins; Olya, who had a dream last night about hugging a dolphin; or Lisa, who likes to read about dolphins. The results showed that girls show better results than boys on this task (71.4\% and $32.1 \%$ respectively; $\mathrm{p} \leq .01)$. Thus, girls are more successful in tasks which require separation of various contexts: a dream, a fantasy, and reality.

In addition, girls also are more successful at task No. 7 of this method. This task includes the following story: "Vanya is not good at writing. He failed the writing test at school. Mom tells Vanya: 'You'll feel better if you go to play with Lera.' Vanya went to visit Lera. She offered to play a word game. Vanya didn't play with Lera and went back home. Why?" Most girls were able to identify the reason for his rejection (47.6\% for girls and $20.0 \%$ for boys; $\mathrm{p} \leq .05$ ). Thus, the results of this test show that girls are better at identifying the reason for someone else's negative emotions.

In general, the results of these tasks for boys and girls allowed us to discover a few notable gender differences. Boys have higher learning ability, while girls display better cognitive flexibility and self-control. Also, girls have higher social intelligence: they better understand social contexts corresponding to various situations, and are able to identify the reasons for someone else's negative emotions more correctly.

Family structure (two-/one-parent family). The results we obtained revealed a few significant differences according to various methods of analysis.

Children from one-parent families do better on the verbal memory test (Sentence Repetition) where a child has to repeat sentences after the examiner. Among the 17 sentences used in this method, children from single-parent families completed one third of the tasks much better than children from two-parent families $(\mathrm{p} \leq .05)$. Generally, this result indicates a higher level of verbal memory.

On the other hand, in the Inhibition test, children from one-parent families did worse in correcting their mistakes in all four tasks than children from two-parent families (this tendency shows in all tests: "naming" and "inhibition"; $\mathrm{p} \leq .05$ ). This result allows us to conclude that children of single-parent families have less self-control.

Additionally, family structure has its influence on the child's emotional intelligence. According to the Theory of Mind test, children from single-parent families 
do worse on task No. 1, where a child is told the following story: "When Andrey opened a cookie box, he saw that Mom had put pasta inside it. He got upset and put the box back in its place. When Andrey's brother came in, he saw a cookie box. What do you think Andrey's brother thought was in the box?" The majority of the children from one-parent families failed the task as compared to those from twoparent families (55.6\% and $18.9 \%$ respectively; $\mathrm{p} \leq .03$ ). These children usually answered that in the brother's view the box contained pasta, which means it is harder for them to imagine how another person sees a situation, and to put themselves into their shoes.

Thus, the data we obtained shows that the absence of one of the parents (father) has a negative impact on the development of self-control and social intelligence.

Family structure (having a sibling or not). We divided the sample into two parts based on the number of children in the family: one child or two.

Children with a sibling get higher scores in the $4^{\text {th }}$ test of the method for visual memory (Memory for Designs) compared to those who have no sibling (22.3 and 17.6 respectively; $\mathrm{p} \leq .03)$. From these particular results, it can be concluded that children who are brought up with siblings have a higher level of learning ability.

At the same time children with siblings make more mistakes in naming figures from the Inhibition method (4.0 and 2.1 respectively; $\mathrm{p} \leq .04$ ); consequently they have a larger percent of self-corrections on this task (2.0 and 0.9 respectively; $\mathrm{p} \leq .01)$. These results indicate that children with siblings show a lower attention span compared to those who are the only children in a family. In the test of inhibition with arrows, children with a sibling are more inclined to correct their mistakes (3.0 and 1.8 respectively; $\mathrm{p} \leq .05$ ), which indicates their high level of self-control.

By this means, the given results show that the number of children in a family is an important factor influencing children's development and impacting their learning ability and self-control.

Mother's level of education. In the analysis we established two groups: the first group included children whose mothers had higher education; the second included those whose mothers had secondary level, dual, or incomplete higher education. Comparison of these two groups revealed crucial differences concerning the number and intensity of children's fears.

For example, children whose mothers have no higher education show emotional problems through the Picture Anxiety Test (PAT); they have more fears of higher intensity than children whose mothers have higher education (19.1 and 10.7 respectively; $\mathrm{p} \leq .02)$. Moreover, children whose mothers have lower educational status are more inclined to avoid fearsome situations ( 17.5 and 8.9 respectively; $\mathrm{p} \leq .01$ ).

Additional analysis revealed certain situations where these differences in intensity of fears among children whose mothers had different educational background came out (Table 1). Namely, children whose mothers had no higher education had more intense fears of the following situations: a doctor's appointment, fireworks, fancy dressed people, and elevator rides. Additionally, they have more intense social fears, such as fear of performing in front of a group of children, and fear of making the acquaintance of peers at a playground; it is more difficult for them to overcome negative (anxious) thoughts; they worry more often about whether they are doing everything right. 
Table 1. Differences in intensity of fears among children whose mothers had different educational background

\begin{tabular}{|c|c|c|c|}
\hline \multirow[b]{2}{*}{ Fearsome situation } & \multicolumn{2}{|c|}{ Mother's level of education } & \multirow[b]{2}{*}{$\mathbf{P}$} \\
\hline & $\begin{array}{l}\text { Higher } \\
\text { education }\end{array}$ & $\begin{array}{l}\text { Secondary level, dual } \\
\text { or incomplete higher } \\
\text { education }\end{array}$ & \\
\hline Doctor's appointment & 0.5 & 1.4 & $\leq 0.01$ \\
\hline Fireworks & 0.1 & 0.6 & $\leq 0.03$ \\
\hline Fancy dressed people & 0.6 & 1.5 & $\leq 0.02$ \\
\hline Elevator rides & 0.3 & 1.4 & $\leq 0.002$ \\
\hline $\begin{array}{l}\text { Fear of performing in front of a group of } \\
\text { children }\end{array}$ & 0.1 & 0.8 & $\leq 0.001$ \\
\hline $\begin{array}{l}\text { Fear of making the acquaintance of peers } \\
\text { at a playground }\end{array}$ & 0.1 & 0.6 & $\leq 0.01$ \\
\hline Overcome negative (anxious) thoughts & 0.2 & 1.1 & $\leq 0.002$ \\
\hline Worrying about doing everything right & 0.3 & 0.9 & $\leq 0.05$ \\
\hline
\end{tabular}

The majority of the aforementioned fearsome situations are connected with differences in the child's social experiences. We may suppose that parents with higher education help their children obtain a wider and more positive experience of social interaction, and thus the situations above are not so "unusual" (worrisome) for them. It is also reasonable to assume that higher education defines a higher social status for a mother and allows her to be more confident and calm in numerous situations, especially those where she and her child are faced with various social institutions (for example, medical center, kindergarten). Mothers without higher education have lower status, which causes insecurity during social interactions with other people - which insecurity is passed on to their children.

Thus, the research revealed a significant influence of the mother's educational status on the child's emotional well-being. But at the same time, it should be noted that there were no evident differences in the implementation of various tasks by children from families with different financial status. This may be due to the fact that the majority of participants identified themselves as from a middle-income stratum.

To sum up this part of the article, we conclude that the research reveals a wide range of very important tendencies reflecting the impact of different socio-demographic and socio-stratifying factors on the child development.

\section{Correlation between the psychological aspects of parent-child relationship and the specific course of child development}

In this part we will discuss how the psychological aspects of mother-child interaction may influence the preschool child's development.

In this research we focused on the system of family relationships on the microlevel of social interaction using the ecological concept of U. Bronfenbrenner (1979). Hence we will analyze such socio-psychological aspects of the maternal position as her emotional state during interaction with the child and her parenting style. In addition to these two aspects, we will also consider the influence of a mother's sense of 
social well-being (optimism or doubts about the future) on the child's development. We may hypothesize that these three aspects play an important role in defining the unique social situation of development at the preschool age.

Attitude toward life's perspectives (optimism/doubt). The question about future perspectives included in the parent questionnaire allowed us to distinguish two groups: the first included mothers who "look ahead optimistically and confidently;" the second included those who "have doubts that their life will proceed successfully." Differences in implementation of various tasks will be considered among children from each of these two groups. Our analysis proved that these differences are connected with levels of success in two tasks: executive functioning and emotion comprehension.

Children whose mothers doubt their future prospects more often correct themselves in the inhibition task within the Inhibition method: in the set with figures (3.6 and 1.7 corrections respectively; $\mathrm{p} \leq .01$ ), as well as in the set with arrows (3.8 and 2.3 corrections respectively; $\mathrm{p} \leq .04$ ). This result indicates that these children have a higher level of self-control, because after making a mistake, they are inclined to stop and correct it. On the other hand, the children of optimistic mothers complete this task much faster (57.5 and 62.4 seconds respectively; $\mathrm{p} \leq .05$ ), but again, do not tend to correct their mistakes. They are evidently more self-assured and confident. Generally, the differences we found allow us to define two strategies toward implementing tasks, depending on the mother's future expectations. The first strategy consists of quick and confident completion of the tasks and the child's confidence of success. The second implies slower processing of the tasks and correction of mistakes.

As for the task of emotion comprehension (TEC), the results showed that children of mothers who are optimistic about their future do better in a task which requires analyzing situations with contradictory motives. These tasks are connected with making the moral choice, and the emotions which children can feel faced with such a choice. For example: In one situation the child wants to eat a cookie, but holds back because he/she did not ask permission. In another, the child eats the cookie, but does not tell his/her mother about this. The child's emotions as a result the two different actions - to eat a cookie without permission or not? To tell mother about the misconduct or not? - were what the child was asked to analyze.

Results showed that children of optimistic mothers tend to feel more positive in the situations where they follow the rules (the child holds him/herself back and is glad that he/she did not eat the cookie without permission), and get upset after breaking them (child is upset for not having told his mother about this misconduct). Thus, the research shows the profitable influence of the mothers' positive attitude toward the future (optimism in future evaluation) on the moral regulation of child's behavior: children of optimistic mothers can more easily submit to social norms and feel good in the case of rules compliance. A different kind of reaction can be seen among children whose mothers "doubt" their future success: these children do not feel negatively about breaking the rules.

Thus, our research showed that the attitude of mothers toward their future success (optimism/doubt) is strongly connected both to the child's strategy in completing tasks (self-control) and to his/her attitude toward moral norms (positive 
reaction about compliance with them). Generally, the results correspond with the notions of L.S. Vygotsky about the role of an adult as a mediator who defines the zone of child's proximal development. In partnership with an adult - more specifically, an emotionally positive adult - the child forms a very important feature of behavior control - the absence of fear of making mistakes.

Mother's emotional state during interaction with the child (positive/negative). Analysis of the mothers ' answers to the question about their emotional state during interaction with their children allowed us to distinguish two groups. The first included those who describe their communication with the child in a positive way: "I feel happy," "I feel joy and a rush of energy." Those who feel negatively formed the second group: "Communication with my child is full of difficulties which turn into scandals," "I cannot handle his/her spontaneous activity," "I am annoyed and irritated."

We found the differences shown the successful implementation of the Inhibition method tasks similar to the ones in the case of the perspective toward life. The children whose mothers are positive about communication with them complete the inhibition task with figures much more quickly (56.0 and 63.4 seconds.; $\mathrm{p} \leq .01$ ). The speed of implementation of this task reveals the level of the ability to control one's cognitive processes and inhibit spontaneous reactions (cognitive flexibility). Children whose mothers are negative about interaction with them have a higher rate of self-corrections in the inhibition task with arrows (3.3 and $1.9 ; \mathrm{p} \leq .05)$.

Thus, the data we obtained shows that self-control is better developed among children whose mothers are mostly negative about communication with their children. In our point of view, this child's attitude (thoroughness, attempts to correct a mistake and complete the task correctly, even though a bit more slowly) may be connected to his/her wish to avoid a negative emotional reaction of an adult to a mistake.

Mother's parenting style (authoritarian/democratic). As to the connection between the parenting style adopted by the mother and the child's development, we will compare two styles based on the mothers' most common answers to the questionnaire, which we interpret as authoritarian and democratic. The authoritarian style implies unconditional submission of a child to the authority of an adult ("I believe that the child must fulfill his/her responsibilities and obey adults"), and the democratic style admits the child's right to have his/her own opinion, independent action, and self-expression ("I believe that the child should have the possibility to freely express his/her emotions and opinion on any subject"). The research showed a difference between implementation of Inhibition and DCCS tasks depending on the mother's parenting style.

Children of authoritarian mothers were more successful in the DCCS task which required sorting cards according to one simple parameter (color) than children of democratic mothers (6.0 and 5.7 respectively; $p=0,005)$. Considering the fact that this task is an easy one, we suppose that children of democratic mothers tend to hurry while doing it, and children of authoritarian mothers pay more attention, as they are used to strict control and try to avoid mistakes.

Furthermore, we found a tendency toward quicker implementation by children of mothers with a democratic parenting style (34.2 and 36.9 seconds; $\mathrm{p} \leq .02)$ in the task of naming figures within the Inhibition method. At the same time they leave more uncorrected mistakes ( 3.1 and 1.3 mistakes; $\mathrm{p} \leq .05)$. The same tendency 
showed up in the inhibition test with figures: children of mothers with a democratic parenting style leave more uncorrected mistakes in this task (5.5 and 2.8 respectively; $\mathrm{p} \leq .04$ ).

The differences found by in our two methods indicate that children of democratic mothers tend to be more impulsive; they try to complete the task quicker and at the same time let themselves make mistakes. On the other hand, children of more authoritarian mothers tend to correct their mistakes, which slows the speed of the task implementation. These facts allow us to assume that among children of more authoritarian mothers, a mistake has a higher emotional value ("fear of making a mistake").

To sum up the material from this part, we would like to emphasize that the influence of all the mentioned aspects (the mother's attitude toward life's perspectives, her emotional state during interaction with the child, and her parenting style) shows up largely in the tasks for inhibition and self-control. It results in two different behavioral strategies of a child toward completing these tasks. The first strategy is to reach the quickest result with less attention to its quality (lack of mistakes). It is connected with such aspects as mother's optimistic attitude toward her future, her positive state during interaction with the child, and her democratic parenting style. The second strategy is to correct mistakes, while taking longer to complete the task. This strategy is connected with mother's doubts about her future success, negative emotions towards communication with the child, and an authoritarian parenting style.

We assumed that the aspects which characterize the mother's position are interconnected (Figure 2). Indeed, our analysis showed that mothers who doubt their future generally adopt the authoritarian parenting style, compared to those who are optimistic. Also they face more difficulties in interaction with their child and almost never feel happiness. Furthermore, mothers with a democratic parenting style more often indicate positive emotions (61.9\% and $31.3 \%)$.

Hence, the regular appearance of the two detected strategies of child behavior in the tasks for inhibition is not accidental. It allows us to conclude that the child's development of executive functioning is influenced by the complex of the mother's values, and emotional and behavioral outlook.

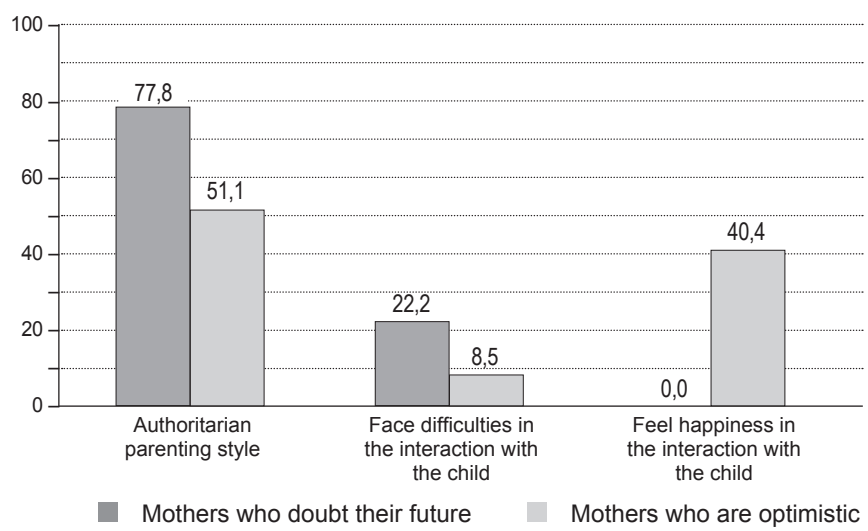

Figure 2. Interconnection between various aspects of mother's attitude (\%) 
So, based on the data obtained, we find that the more positive relationships (optimism, democratic parenting style, and positive emotional background) form a supportive environment for developing confidence in a child; such children usually aim at quick success. On the other hand, a negative relationship (mother's doubts about future success, an authoritarian parenting style, and negative emotions during interaction with the child) motivates a child to avoid failure. It influences the development of self-control.

\section{Conclusion}

Nowadays the notion of the "social situation of development" is interpreted in different ways, although, according to L.S. Vygotsky, this term specifically describes a certain relationship between a child and significant adults. Our research showed that using this term requires acknowledging a whole set of factors which determine child development.

In this work we studied the interconnection between the specifics of the social situation of development, such as socio-demographic factors and the parent-child relationship, and the development of mental functioning in preschool age children.

For instance, an important role is played by gender and various socio-stratifying factors (mother's educational level, family structure). We found a connection between socio-demographic factors and the development of preschooler's intellectual and emotional spheres. The most important result revealed was the connection between mother's educational level and the quantity and intensity of child's fears.

But the main idea which we would like to emphasize is the specific influence of mother-child relationships - such as the mother's attitude toward life, her emotional state, and her parenting style - on the development of preschool children. Our analysis showed the interrelationship between these features of the motherchild relationship, and the strategy her child uses while performing executive function tasks, which show his/her ability for self-control and regulation of his/her behavior and cognitive processes. Additionally, we assume here that we are dealing with a complex of interconnected factors of parenting which influence the child's choice of behavioral strategy, which is either seeking success or avoiding failure.

The results of the current study, therefore, confirm previous conclusions that maternal positive parenting is among the strongest predictors of children's EF (executive function), but also provide some new associations between aspects of the social environment and peculiarities of child's mental and emotional development. These results are of great practical importance, considering that both classical and modern research consider the development of executive functions as the crucial factor in a child's readiness for school, and a precondition for his/her future academic progress.

\section{Limitations}

The main limitation of this research is the number of participants. The small sample size led to difficulties in conducting statistical analysis: some of the socio-demographical groups couldn't be compared, and there is a possibility that some of the differences couldn't be shown. 
Furthermore, we didn 't analyze the correlations between child development and the father's answers, which could have enriched our interpretations and supplemented the results.

Moreover, it should be noted that statistical norms of task implementation for Russia haven 't yet been developed, which complicates the analysis of the results. In the future the authors intend to increase the sample, as well as find new ways of data processing, to create norms and continue the work with standardized methods.

\section{Acknowledgements}

The study of executive functioning was performed by the Russian Science Foundation (RNF), project № 16-18-00073 "Neurocognitive longitudinal study of executive functions in childhood."

\section{References}

Alarcón-Rubio, D., Sánchez-Medina, J. A., \& Prieto-García, J. R. (2014). Executive function and verbal self-regulation in childhood: Developmental linkages between partially internalized private speech and cognitive flexibility. Early Childhood Research Quarterly, 29(2), 95-105. doi: 10.1016/j.ecresq.2013.11.002

Anastasy, A. (1956). Intelligence and family size. Psychological Bulletin, 53(3), 198-222. doi: $10.1037 / \mathrm{h} 0047353$

Andreeva, T. N. (1994). Kognitivnye i lichnostnye harakteristiki detej v mnogodetnoj semye [Cognitive and personal characteristics of the children in a large family]. (PhD dissertation). Moscow: Psychological Institute of RAE.

Ardila, A., Rosselli, M., Matute, E., \& Guajardo, S. (2005). The influence of the parents' educational level on the development of executive functions. Developmental Neuropsychology, 28(1), 539-560. doi: 10.1207/s15326942dn2801_5

Belmont, L., \& Marolla, F. (1973). Birth order, family size and intelligence. Science, 193, 10941101.

Bjorklund, D. F., \& Kipp, K. (1996). Parental investment theory and gender differences in the evolution of inhibition mechanisms. Psychological Bulletin, 120(2), 163-188. doi: 10.1037/00332909.120.2.163

Blair, C., Raver, C. C., Berry, D. J., \& Family Life Project Investigators. (2014). Two approaches to estimating the effect of parenting on the development of executive function in early childhood. Developmental Psychology, 50(2), 554-565. doi: 10.1037/a0033647

Bozhovich L. I. (2008) Lichnost i ee formirovanie $v$ detskom vozraste [Personality and its formation in childhood]. St. Petersburg: Piter.

Bronfenbrenner, U. (1979). The ecology of human development: Experiments by nature and design. Cambridge, MA: Harvard University Press.

Bulgarelli, D., Molina, P. (2016). Early childcare, maternal education and family origins: Differences in cognitive and linguistic outcomes throughout childhood. Revista de Cercetare si Interventie Sociala [Journal of Research and Social Intervention], 52, 5-25.

Carlson, S. M., \& Moses, L. J. (2001). Individual differences in inhibitory control and children's theory of mind. Child Development, 72(4), 1032-1053. doi: 10.1111/1467-8624.00333

Chasiotis, A., Kiessling, F., Hofer, J., \& Campos, D. (2006). Theory of mind and inhibitory control in three cultures: Conflict inhibition predicts false belief understanding in Germany, Costa 
Rica and Cameroon. International Journal of Behavioral Development, 30(3), 249-260. doi: $10.1177 / 0165025406066759$

Cheie, L., Veraksa, A., Zinchenko, Yu., Gorovaya, A., \& Visu-Petra, L. (2015). A cross-cultural investigation of inhibitory control, generative fluency, and anxiety symptoms in Romanian and Russian preschoolers. Child Neuropsychology, 21(2), 121-149. doi: $10.1080 / 09297049.2013 .879111$

Chernov, D. N. (2009). Vliyanie stilya detsko-roditelskih otnoshenij na obuchenie mladshih shkolnikov [Influence of parent-child relationship style on education of younger pupils]. Kulturno-istoricheskaya psihologiya [Cultural-Historical Psychology], 1, 74-84.

Dubi, K., \& Schneider, S. (2009). The Picture Anxiety Test (PAT): A new pictorial assessment of anxiety symptoms in young children. Journal of Anxiety Disorders, 23, 1148-1157. doi: 10.1016/j.janxdis.2009.07.020

Dubi, K., Schneider, S., \& Lavellee, K. (2012). The Picture Anxiety Test (PAT). Psychometric Properties in a Community Sample of Young Children. Swiss Journal of Psychology, 71, 7381. doi: $10.1024 / 1421-0185 / \mathrm{a} 000073$

Dumitrashku, T. A. (1996). Struktura semyi i kognitivnoe razvitie detej [Family structure and the cognitive development of children]. Voprosy Psihologii [Issues in Psychology], 2, 104-112.

Elkonin, D. B. (1960). Detskaya psihologiya [Child psychology]. Moscow: Prosveshchenie.

Filippetti, V. A., Richaud, M. C. (2012). A Structural Analysis of Executive Functions and Socioeconomic Status in School-Age Children: Cognitive Factors as Effect Mediators. The Journal of Genetic Psychology, 173(4), 393-416. doi: 10.1080/00221325.2011.602374

Fitzpatrick, C., McKinnon, R. D., Blair, C. B., \& Willoughby, M. T. (2014). Do preschool executive function skills explain the school readiness gap between advantaged and disadvantaged children? Learning and Instruction, 30, 25-31. doi: 10.1016/j.learninstruc.2013.11.003

Goodman, R., Slobodskaya, H., \& Knyazev, G. (2005). Russian child mental health A cross-sectional study of prevalence and risk factors. European Child \& Adolescent Psychiatry, 14(1), 28-33. doi: 10.1007/s00787-005-0420-8

Hammond, S. I., Müller, U., Carpendale, J. I. M., Bibok, M. B., \& Liebermann-Finestone, D. P. (2012). The effects of parental scaffolding on preschoolers' executive function. Developmental Psychology, 48, 271-281. doi: 10.1037/a0025519

Kochetova, Yu. A. (2012). Strahi sovremennyh doshkolnikov i ih svyaz sosobennostyami detskoroditelskih otnoshenij [Fears of modern preschoolers and their relation with the characteristics of parent-child relationship]. Psihologicheskaja Nauka i Obrazovanie [Psychological Science and Education], 3, 77-87.

Kon, I. S. (2003). Rebyonok i obshchestvo [Child and Society]. Moscow: Akademia.

Korkman, M. (1999). Applying Luria’s diagnostic principles in the neuropsychological assessment of children. Neuropsychology Review, 9(2), 89-105. doi: 10.1023/A:1025659808004

Korkman, M., Kirk, U., \& Kemp S. L. (2007). NEPSY II. Administrative manual. San Antonio, TX: Psychological Corporation.

Kovan, F. A., \& Kovan, K. P. (1989). Vzaimootnosheniya v supruzheskoj pare, stil roditel'skogo povedeniya i razvitie trekhletnego rebenka [Relationship in a married couple, parental behavior style and the development of a three year old child]. Voprosy Psihologii [Issues in Psychology], 4, 110-118.

Lan, X., Legare, C. H., Ponitz, C. C., Li, S., \& Morrison, F. J. (2011). Investigating the links between the subcomponents of executive function and academic achievement: A cross-cultural analysis of Chinese and American preschoolers. Journal of Experimental Child Psychology, 108(3), 677-692. doi: 10.1016/j.jecp.2010.11.001 
Leerkes, E. M., Blankson, A. N., O’Brien, M., Calkins, S. D., \& Marcovitch, S. (2011). The relation of maternal emotional and cognitive support during problem solving to pre-academic skills in preschoolers. Infant and Child Development, 20, 353-370. doi: 10.1002/icd.728

Lisina, M.I. (2009). Formirovanie lichnosti rebenka v obshchenii [Formation of child`s personality through communication]. St. Petersburg: Piter.

Lucassen, N., Kok, R., Bakermans-Kranenburg, M. J., IJzendoorn, M. H. van, Jaddoe, V. W. V-K., Hofman, A., Verhulst, F. C., Berg, MP van den \& Tiemeier, H. (2015). Executive functions in early childhood: The role of maternal and paternal parenting practices. British Journal of Developmental Psychology, 33(4), 489-505. doi: 10.1111/bjdp.12112

Matte-Gagné, C., \& Bernier, A. (2011). Prospective relations between maternal autonomy support and child executive functioning: Investigating the mediating role of child language ability. Journal of Experimental Child Psychology, 110, 611-625. doi: 10.1016/j.jecp.2011.06.006

Pons, F., \& Harris, P. L. (2000). Test of Emotion Comprehension. Oxford: Oxford University Press.

Pons, F., Harris, P. L., \& de Rosnay, M. (2004). Emotion comprehension between 3 and 11 years: Developmental periods and hierarchical organization. European Journal of Developmental Psychology, 1, 127-52. doi: 10.1080/17405620344000022

Raven, J., Raven, J. C., \& Court, J. H. (1998). Manual for Raven's progressive matrices and vocabulary scales. Section 2: The coloured progressive matrices. Oxford: Oxford Psychologists Press.

Roskam, I., Stievenart, M., Meunier, J-Ch., \& Noel, M.-P. (2014). The development of children's inhibition: Does parenting matter? Journal of Experimental Child Psychology, 122, 166-182. doi: 10.1016/j.jecp.2014.01.003

Sarsour, K., Sheridan, M., Jutte, D., Nuru-Jeter, A., Hinshaw, S., \& Boyce, W. T. (2010). Family socioeconomic status and child executive functions: The roles of language, home environment, and single parenthood. Journal of the International Neuropsychological Society, 17(1), 120-132. doi: 10.1017/S1355617710001335

Smirnova, E. O. (1998). Razvitie voli I proizvolnosti v rannem i doshkolnom vozrastah [Development of will and arbitrariness in early and preschool age]. Moscow: Institut prakticheskoj psikhologii; Voronezh: NPO "MODEHK".

Smirnova, E. O. (1980). Vliyanie formi obshcheniya so vzroslym na effektivnost' obucheniya doshkol'nikov [Influence of communication with an adult on the efficiency of preschool education]. Voprosy psihologii [Issues in Psychology], 5, 105-112.

Smirnova, E. O., Sobkin, V. S., Asadulina, O. E., \& Novakovskaya, A. A. (1999). Specifika ehmocionalno-lichnostnoj sfery doshkol'nikov, zhivushchih $\mathrm{v}$ nepolnoj semye (na material detskih risunkov) [Specificity of emotional-personal sphere of preschool children living in single-parent family (based on children's drawing]. Voprosy Psihologii [Issues in Psychology], $6,18-28$.

Sobkin, V. S., \& Marich, E. M. (2002). Sociologiya semejnogo vospitaniya: doshkolnyj vozrast. Trudy po sociologii obrazovaniya. T. VII. Vyp. XII. [Sociology of family education: preschool age. Works on the sociology of education. Vol. VII. no. XII.]. Moscow: Institute for the Sociology of Education RAE.

Sobkin, V. S., \& Skobeltsina, K. N. (2011). Igrovye predpochteniya sovremennyh doshkolnikov (po materialam oprosa roditelej) [Game preferences of modern preschool children (based on a survey of parents)]. Psihologicheskaya Nauka i Obrazovanie [Psychological Science and Education], 2, 56-67.

Sobkin, V. S., \& Skobeltsina, K. N. (2015). Shared activities of parents with their preschool children during family pastime. Psychology in Russia: State of the Art, 8(2), 52-60. doi: 10.11621/ pir.2015.0205 
Sobkin, V. S., Skobeltsina, K. N., \& Ivanova, A. I. (2011). Zhiznennye orientacii roditelej detej doshkolnogo vozrasta [Life orientation of preschool children's parents]. Sociologiya obrazovaniya. Trudy po sociologii obrazovaniya. T. XV. Vyp. XXVI [Sociology of education. Works on the sociology of education. Vol. XV. No. XXVI]. V.S. Sobkin (Ed.). (pp. 87-105). Moscow: Institute for the Sociology of Education RAE.

Sobkin, V. S., Skobeltsina, K. N., Ivanova, A. I., \& Veryasova E. S. (2013). Sociologiya doshkolnogo detstva. Trudy po sociologii obrazovaniya. T. XVII. Vyp. XXIX [The sociology of preschool childhood. Works on the sociology of education. Vol. XVII, no. XXIX]. Moscow: Institute for the Sociology of Education RAE.

Ursache, A., Blair, C., Stifter, C., \& Voegtline, K. (2013). Emotional reactivity and regulation in infancy interact to predict executive functioning in early childhood. Developmental Psychology, 49, 127-137. doi: 10.1037/a0027728

Veraksa, A. N., Yakupova, V. A., \& Martynenko, M. N. (2015). Simvolizaciya v structure sposobnostej detej doshkolnogo i shkolnogo vozrasta [Symbolization in the structure of abilities of preschool and school-age children]. Kulturno-Istoricheskaya Psihologiya [Cultural-Historical Psychology], 2, 48-56.

Visu-Petra, L., Cheie, L., Benga, O., \& Alloway, T. P. (2011). Effects of anxiety on memory storage and updating in young children. International Journal of Behavioral Development, 35(1), 38-47. doi: 10.1177/0165025410368945

Visu-Petra, L., Cheie, L., Benga, O., \& Miclea, M. (2012). The structure of executive functions in preschoolers: An investigation using the NEPSY battery. Procedia - Social and Behavioral Sciences, 33, 627-631. doi: 10.1016/j.sbspro.2012.01.197

Vygotsky, L. S. (1984). Sobranie sochinenij: V 6-ti tomakh. T. 4. Detskaya psihologiya [Collected works: In 6 volumes . Vol. 4. Child psychology]. Moscow: Pedagogika.

Willoughby, M. W, Wirth, R. J, Blair C. \& The Family Life Project Investigators. (2012). Executive function in early childhood: Longitudinal measurement invariance and developmental change. Psychological Assessment, 24, 418-431. doi: 10.1037/a0025779

Zaporozhets, A. V. (1986). Izbrannye psihologicheskie trudy: V 2-h tomah. Tom 1. Psihicheskoe razvitie rebenka [Selected psychological works: In 2 volumes. Vol. 1. Mental development of the child]. Moscow: Pedagogika.

Zelazo, P. D. (2006). The Dimensional Change Card Sort (DCCS): A method of assessing executive function in children. Nature Protocols, 1, 297-301. doi: 10.1038/nprot.2006.46 